\section{Harvesting of whales}

SIR - Professor A. S. Blix is reported (Nature 360, 523; 1992) as saying that "any resource that can be harvested on a sustainable basis... should be harvested .... Not doing so is a waste of resources." Professor L. Walløe expressed a similar view in a public debate with me recently in Stockholm. If their view were to prevail, we could say goodbye to all national and regional parks and to the greater part of the planet's wildlife and flora.

A more enlightened - not to say civilized - view, which is in accord with the decisions of the UN Conference on Environment and Development, is that if wild animals or plants are harvested, then such harvesting should be limited so that it is sustainable. Furthermore, according to both the UN Convention on the Law of the Sea and the Agenda 21 document from UNCED, "living marine resources" that are already depleted to below their maximum potential level of productivity must be permitted to increase to that level. Such restoration can be achieved by restraining any catches to be less than the currently sustainable amount, which can include making catches temporarily zero. Where there is great uncertainty about the catch rates that might be sustainable - as there is with whales - then wise management calls for more cautious quota decisions.

Those are the elements of the policy of the International Whaling Commission (IWC) and, increasingly, that of governments and regional international organizations seeking to restore overfished fish stocks to higher levels of sustainable productivity. Decisions for temporary zero catch quotas in such conditions have nothing whatsoever to do with whether "... . [whale] populations are in a particularly precarious state ..." or whether a particular catch number will or will not pose "... a serious threat to the remaining population."

Then, there is virtually no scientific or political "... dispute over the algorithm ..." for calculating catch quotas for minke whales in the northeast Atlantic. The present difficulty arises from the fact that the IWC Scientific Committee has agreed, unanimously, that these whales declined in number continuously from at least 1953 to 1983 (the last year for which there are appropriate data) under the impact of Norwegian whaling. This means that "restoration" is mandatory under international policies and rules. So quotas set by the IWC would be cautious and, specifically, less than Norwegian whalers want for economic reasons and have been promised by Walløe and other Norwegian officials.
That is the main reason the Norwegian government has unilaterally decided to allow its whalers to resume next year. Public statements that the national quotas have been calculated using the IWC algorithm should be taken with a large pinch of salt.

You report other (unnamed) Norwegian scientists as feeling that the "generous" allocations for lethal research on whales have more to do with politics than with science. In this connection it is perhaps worth noting that the Norwegian government has just decided to make a roughly equivalent sum available for propaganda to "explain" why Norway has decided to isolate itself from the rest of the world on all matters scientific, managerial and political concerning whaling.

\section{Sidney J. Holt}

International Fund for Animal Welfare, Podere II Falco,

06062 Città della Pieve (PG), Italy

SIR - For the past three years I have been studying the biology of minke whales off the west coast of Scotland where, off the Hebridean island of Mull, a small whale-watching tourism industry is developing. The whales in this area belong to what the International Whaling Commission calls the 'North East Atlantic Stock'. The Norwegian government has announced plans to resume whaling next year on this same stock when the animals are feeding in the Barents Sea, off Spitzbergen, and along the west coast of Norway.

In this context, I should like to correct the figures reported in an "Alternative view on whaling" (Nature 360, 523; 1992). The estimate quoted of about 80,000 minke whales (actually 86,700 ) is for the northeast Atlantic, not the world. The 95 per cent confidence limits for this estimate range from 58,000 to 115,000 . There has never been a "previous estimate" as low as 18,000 . For several years, Norwegian scientists insisted on a figure of 113,000 obtained from marking experiments (I. Christiensen \& K. J. Rorvik, Rep. Int. Whal. Commn. 31, 255-257; 1981). Then in 1983 they agreed with the IWC Scientific Committee on 66,000 , and later agreed to a revised figure of 60,000 , with a similar confidence limit range. Corresponding pre-exploitation figures are calculated simply by adding catches to estimates of current numbers, with some correction for births and natural deaths. For this reason, estimates of depletion are more robust than estimates of stock number. Since 1976, the IWC has classed stocks less than 54 per cent of their preexploitation number as "Protection
Stocks" with automatic zero catch quotas. The IWC resolution of 1991 endorsing a revised procedure for calculating catch quotas explicitly reaffirmed that there must be no catching from stocks which would have been classed as "Protection Stocks" under the old rules. Such stocks include the northeast Atlantic stock which was so classified in 1985. There are no significant differences between the estimates of the mid-1980s and the recent ones. Improved calculations presented to the IWC Scientific Committee in 1992 strongly confirm that the catch limit should remain at zero.

Vassili Papastavrou

University of Bristol,

Department of Zoology,

School of Biological Sciences,

Woodland Road, Bristol BS8 1UC, UK

\section{Culture deposits}

SIR - Some years ago, the story goes, on receiving a refusal to a request for a certain virus, the enterprising petitioner succeeded in isolating the virus from the envelope that enclosed the reply. Most workers make newly described microbes accessible and deposit living cultures in a publicly available collection. This is important to avoid losing the microbe and to enable others to verify the published observations.

Some people do refuse to make specimens available, however, because of the fear of being overtaken by others. Such unpleasant people are few and should not be allowed to impede free science. Unfortunately, their cause is facilitated by one of the rules of the International Code of Botanical Nomenclature ${ }^{1}$. This rule applies to yeasts and other fungi and stipulates that only preserved, not living, specimens of newly described species need be deposited. A preserved specimen of a new species is useless for most purposes. Furthermore, many of its characteristics, given in the published description, are unverifiable. Examples of such taxonomically valid, yet unverifiable, species include two yeasts, Filobasidiella depauperata ${ }^{2}$ and Myxozyma sirexii

A rule enabling the publication of observations that cannot be confirmed is anti-scientific. It should be changed, so that the deposit of living specimens of all new species and their accessibility is a condition of accepting the validity of the species.

\section{J. A. Barnett}

School of Biological Sciences,

University of East Anglia,

Norwich NR4 7TJ, UK

1. International Code of Botanical Nomenclature (Koeltz Königstein, 1988)

2. Samson, R.A., Stalpers, J.A. \& Weijman, A.C.M. Antonie van Leeuwenhoek 49, 447-456 (1983).

3. Spaaij, F., Weber, G. \& van der Walt, J.P. System. appt Microbiol. 15, 427-431 (1992) 